\title{
THE ROLE OF FORUM KERUKUNAN UMAT BERAGAMA (FKUB) FOR RELIGIOUS HARMONY AND THE RIGHTS OF FREEDOM OF RELIGION OR BELIEF (FORB)
}

\author{
Ahmad Faqih \\ Universitas Gadjah Mada (UGM), Yogyakarta, Indonesia \\ E-mail: ahmadfaqihsddq@ugm.mail.ac.id
}

\begin{abstract}
This study aims to describe the extent of the Forum of Religious Harmony's (FKUB) roles and duties as a driving force for harmony and right protection for Freedom of Religion or Belief (Forb). To answer the problem, this paper formulates two questions: (1) how is the role of FKUB in protecting Forb rights and maintaining religious harmony and (2) does the formation of FKUB in protecting Forb as well as maintaining religious harmony in Indonesia work successfully or not. This study examines several regulations formulated regarding the right to freedom of religion or belief and the basic principles of human rights in Indonesia. This study found that although FKUB has been established based on the principles of justice and diversity of society in Indonesia, its programs tend to only focus on one issue such as licensing places of worship, while the issue of empowering religious community, fostering tolerance, and fighting radicalism are less appreciated.
\end{abstract}

Keywords: Forum Komunikasi Umat Beragama; Forb; Human Rights; Religious Harmony.

Article history: Received: 12 August 2020; Revised: 11 September 2020; Accapted: 23 December 2020; Available online: 01 March 2021

\section{How to cite this article:}

Faqih, Ahmad. "The Role of Forum Kerukunan Umat Beragama (FKUB) for Religious Harmony and the Rights of Freedom of Religion or Belief (Forb)". Religio: Jurnal Studi Agama-agama 11, no. 1 (2021): 65-82. https://doi.org/10.15642/religio.v11i1.1662 


\section{Introduction}

The Universal Declaration of Human Rights (UDHR) has been agreed internationally as a norm that protects the fundamental rights of an individual and this international UDHR convention has been ratified in Indonesia. ${ }^{1}$ The basic rights of human rights can include freedom of speech, freedom from deprivation, to freedom of religion and belief. As for the obligation of a state in protecting fundamental human rights, International Covenant on Civil and Political Rights (ICCPR) emphasizes that the State must guarantee the implementation of human rights principles in the form of the fulfillment of civil and political rights, one of which is the right to freedom of religion or belief (Forb) which is derogable and nonderogable. The efforts of Indonesian state in regulating freedom and religious harmony have actually been formed in accordance with the human rights principles contained in the UDHR which was inaugurated in December 1948. Even 3 years earlier, Indonesia passed the 1945 Constitution which regulates freedom of religion and harmony of religious communities. The guarantee of the right to Forb has been confirmed in articles $28 \mathrm{E}$ and $28 \mathrm{I}$, article 29 of the Constitution, Article 22 paragraph (1) and article 4 of Law no. 39 of 1999 concerning Human Rights, and a number of other laws and regulations. $^{2}$

The religious governance is not merely influenced by the principles of human rights and protection of the rights to freedom of

\footnotetext{
${ }^{1}$ In addition there are 8 of the 9 main international human rights instruments that have been ratified by Indonesia, including the Convention on the Elimination of All Forms of Discrimination Against Women (Law no. 7/1984); Convention on the Rights of the Child (Keppres no.36/1990), including the Optional Protocol to the Convention on the Rights of the Child on the Involvement of Children in Armed Conflict (Law no. 9/2012) and the Optional Protocol to the Convention on the Rights of the Child on the Sale of Children, Child Prostitution and Child Pornography (Law no. 10 of 2012); Convention Against Torture and Other Cruel, Inhuman, or Degrading Treatment or Punishment (Law no. 5/1998); International Convention on the Elimination of All Forms of Racial Discrimination, 1965 (Law no. 29/1999); International Covenant on Economic, Social, and Cultural Rights (Law no. 11/2005); International Covenant on Civil and Political Rights (Law no. 12/2005); Convention on the Rights of Persons With Disabilities (Law no.19 / 2011); International Convention on the Protection of the Rights of All Migrant Workers and Members of Their Families (Law no. 6/2012).

2 The law on Human Rights was further emphasized in the International Covenant on Civil and Political Rights (ICCPR) which was later ratified by Indonesia (Law no. 12/2005).
} 
religion and belief, but is also influenced by the state paradigm towards the term religion which initially focused on religious harmony. In the history of the development of religious governance in Indonesia, the legal basis for freedom of religion and belief began to emerge after the 1998 reform where religious freedom previously described in the Constitution was strengthened through laws and a new chapter on human rights in constitutional amendments. Although many politics and laws governing religious freedom are legacies of the pre-1998 authoritarian era ${ }^{3}$. Therefore, the status of the rights to freedom of religion or belief is in an important position in the study of human rights, both in relation to the constitutional configuration to the discourse on legal politics in Indonesia.

In Article 29 paragraph (2) of Constitution, it is stated that the state guarantees the freedom of every citizen to embrace his or her own religion and worship according to his or her respective religion and belief. In 1965, a law on the prevention of misuse and/or blasphemy was also enacted and subsequently updated to Law Number 5 of 1969 concerning Prevention of Religious Abuse and/or Blasphemy. In article 28J of Constitution (second amendment, 2000) religious limitation that do not contradict the principles of the International Covenant on Civil and Political Rights (ICCPR) as ratified by Indonesia in 2005 are required ${ }^{4}$. In human rights literature, limitations on human rights are clearly permissible, and there is nothing against this. In fact, what often becomes a problem is the extent to which the basics and conditions of the restrictions are allowed. Limitation on human rights are necessary and permitted with the intention of guaranteeing the recognition of freedom and justice for the rights of others, and "limiting without violating" the other's rights. This includes limitation with the aim of protecting public safety, public order, public health, public morals, and the fundamental rights and freedoms of others ${ }^{5}$.

In addition, legal framework based on freedom and religious harmony has also established by government in a joint ministerial regulation that protects and maintains religious harmony or what is

\footnotetext{
${ }^{3}$ Zainal Abidin Bagir, The Politics of Law of Religious Governance in Muslim and Religious Plurality (London: Routledge, 2018), 284.

${ }^{4}$ In 2005, Indonesia ratified the International Covenant on Civil and Political Rights (ICCPR) become Law No. 12 of 2005.

${ }^{5}$ Zainal Abidin Bagir and Asfinawati, et. al., Membatasi Tanpa Melanggar (Yogyakarta: Center for Religious and Cross-cultural Studies, 2019), 7.
} 
known as the Joint Regulation of the Minister of Religion and the Minister of Home Affairs (PBM). No. 9 and 8 of 2006 about the Maintenance of Religious Harmony, Empowerment of the Forum for Religious Harmony (FKUB) and the Construction of Houses of Worship. This policy aims to increase intra and inter-religious harmony by empowering the community, and religious leaders. This PBM was formed as a form of government responsibility and guarantee in protecting religious communities from exercising their religious rights and also maintaining order and harmony between religious communities. This PBM also explains the relationship between government agencies and FKUB in realizing religious harmony.

However, the guarantee of the protection of the right to freedom of religion or belief does not automatically run in accordance to the agreed written rules, a number of cases related to discrimination and violations to the right to freedom of religion or belief committed by duty-bearer (State) and a number of regulations actually hinder the rights holders enjoy their rights to freedom of religion or belief. Wahid foundation in its 2016 report mapped at least there are several factors that led to the case of human rights violations, including (1) the existence of minority target groups (Ahmadiyyah, Shia, people of indigenous religion); (2) form of regulations that are discriminatory and then lead to intolerance, hate speech, attacks, criminalization violence, and even murder; (3) policies that take sides and discriminate against minority groups as an option for state stability and prevent large-scale continuing conflicts; and (4) approved laws that could potentially threaten Forb are still being used in some areas. ${ }^{6}$

In 2018, Setara Institute issued its report that stated by mid2018 there were 109 cases of violation to religious freedom and religious intolerance, with 136 actions taking place in 20 provinces in Indonesia ${ }^{7}$. Most of these violations are committed by state actors

6 Muhammad Hafiz and Alamsyah M. Djafar, Ringkasan Kebijakan Kemerdekaan Beragama atau Berkeyakinan di Indonesia dan Perlindungan Negara (Jakarta: Wahid Foundation, 2016), 5.

${ }^{7}$ Most of the violations occurred in DKI Jakarta, with 23 incidents. This is a new history where in 11 years SETARA Institute has conducted monitoring research, this is the first time that a province has been able to beat West Java in terms of the quantity of violations. In West Java, there were 19 violations. West Java is in the second place after DKI Jakarta. East Java is in third place with 15 violations. In 
with the types of criminalization and discrimination violations, both in the form of direct actions (commission) and policies (by rule), as most prominently related to licensing regulations for building houses of worship for religious people. While the rest is carried out by nonstate actors who are dominated by members of certain community organizations. The dominant actions carried out by non-state actors are acts of intolerance, blasphemy, violence, hate speech to terror. These violations do not only injure the rights to freedom of religion or belief but also affects other rights, such as economic rights, education and a decent living. Thus, it can be seen that issue of human rights violations and the right to freedom of religion and belief is very diverse. It is not only related to licensing of places of worship, but also to discriminatory treatment, intolerance, violence against religious minorities, speech of hatred to religious terror.

By looking at this case, the government need to review the role of non-governmental institutions such as the Forum for Religious Harmony (FKUB) which was formed with the aim to help maintaining religious relations and to protect the freedom of religion and belief rights of each individual. The existence of FKUB as the right-hand of the government in the effort of maintaining religious harmony is considered important for the stability of religious relations. Not only in maintaining harmony with others but also protecting the freedom of religious people in carrying out religious activities. So, it is considered important to examine the role of the formation of the FKUB institution in efforts to protect freedom of religion and or belief and religious harmony in Indonesia.

This paper tries to formulate two questions: the first is related to the role of FKUB in protecting freedom of religion or belief as well as their efforts for maintaining religious harmony and the second whether the formation of FKUB, as a driving force of religious harmony and protection of Forb, is optimal or it is the opposite (failed). To help figure out of these questions, the researcher need to examine the laws and regulations regarding to the role and strategy of FKUB in the discourse of fulfilling the rights to freedom and religious

fourth place is DI Yogyakarta. In this special area which claimed to be a "city of tolerance", 9 violations occurred. NTB completes the ranking of the top five provinces with the most violations. Until mid-2018 there were 7 incidents of Forb violations. Look at https://setara-institute.org/laporan-tengah-tahun-kondisikebebasan-beragamaberkeyakinan-dan-minoritas-keagamaan-di-indonesia-2018/. 
harmony in Indonesia, to examine whether the implementation of government policies through FKUB in protecting religious freedom and religious harmony is optimal or not. The type of this research is a normative legal research by collecting data through literature studies, statutory regulations, and special reports related to research topics. The normative legal research in question means looking at the principles of law and regulations. By examining the basics of law, I obtain the data and qualitatively analyze it and present it in an analytic descriptive way.

\section{Implementation of Government Policies to the Pro- tection of Forb Rights and Religious Harmony}

Prior to the affirmation of the Covenant on Civil and Political Rights (ICCPR), Indonesia through its constitutional regulations 1945 has established a legal basis regarding the right to religious freedom as part of human rights that must be protected by the government. This is stipulated in the 1945 Constitution, Article 28I paragraph (4). In that article, it is explained that the state is obliged to protect the right to freedom of religion and the right to perform worship in accordance with its religion and belief. There are 6 religions referred to in this law, namely Islam, Protestant Christianity, Catholicism, Hinduism, Buddhism and Confucianism. The majority of Indonesia's population is Islam (80\%), the rest are Christian (9\%), Catholic $(6 \%)$, Hindu (3\%), Buddhist and others $(2 \%)^{8}$. However, not all provinces in Indonesia have a majority Muslim population, there are some areas where Islam is a minority such as in Papua, Manado, Bali. With this demographic data, it shows the unequal distribution of the population of religions that demands the government to maintain social balance through its impartial policies while taking into account this diversity. However, not infrequently the policies on religious life and public policies actually appear discriminatory and are considered to be detrimental to one party (majority), causing a social imbalance and a common challenge in maintaining religious harmony and freedom. The terms majority and minority should not apply in a regulation built on the basis of justice and equality. However, the stigma of society towards one group against another group will continue to exist and cause group segregation (majority-minority). This indirectly affects the

8 https://balitbangdiklat.kemenag.go.id/berita/lingkungan-dan-peran-strategisfkub-dalam-pemeliharaan-kerukunan-umat-beragama-dan-persatuan-nasional. 
government's legal framework in formulating a policy based on social stability. Thus, the influence of a majority power in legal regulation is a violation of law in a democratic country based on social justice for all its people. This kind of violations also often occurs against a religious group which in fact is a minority religion from the regional scale to the state and local religions with intolerant actions towards adherents of that religion.

Religious tensions in various areas between the majority (Islam) and minority (Christian) religions have caused the narrative of religious harmony to become tainted so that conflicts in the name of religion are increasingly being heard. ${ }^{9}$ In fact, some areas where Muslim are minorities have also suffered the consequences and pressure from this case. Moreover, the propaganda messages spread through the mass media continue to drive public opinion about the failure of tolerance in this country. Over the past 60 years, various legal actions have facilitated discrimination against minority beliefs, including the establishment of the Ministry of Religion in 1946, the 1965 Presidential Decree on blasphemy, the 1969 Ministerial Decree on the establishment of places of worship, and other regulations at the central, provincial and district levels. Regarding the issue of building houses of worship, during the regime of Soeharto era, the Minister of Religion Muhammad Dahlan (1969) issued a Joint Decree on the construction of places of worship. This regulation is based on the concern of Muslims about the Christianization movement that has occurred in various regions. With the establishment of several churches in Muslim-majority areas, Muslims think there is a Christianization project behind the construction of these places of worship, likewise, with the construction of mosques that occur in Christian-majority areas. ${ }^{10}$ This decree requires the construction of places of worship only with the approval of local governments, religious organizations and religious leaders. However, in practice, some regional officials have issued policies that are discriminatory and limit religious minorities to build houses of worship. In Aceh Singkil,

9 For further reading, look at Mujiburrahman, Feeling Threatened: Muslim-Christian Relation in Indonesia's New Order (Leiden: Amsterdam University Press, 2006); Melissa Crouch, Law and Religion in Indonesia (London: Rotledge, 2014); Sumanto Al Qurtuby, Religious Violence and Conciliation in Indonesia: Christian and Muslims in the Moluccas (London: Rotledge, 2016).

10 Human Rights Watch, "In the Name of Religion: Violations of Religious Minorities in Indonesia” (USA: Human Rights Watch, 2013), 32. 
in 1979, Christians were forced to sign an agreement to have only one church and four small church in the area. ${ }^{11}$ As a result, Christians feel restricted and discriminated against by these regulations and find it difficult to obtain permits to build houses of worship.

Regarding to the maintenance of religious harmony, the government held a deliberation on November 1969 involving several religions, especially religions that were prone to conflict. This meeting involved Islamic, Christian, Hindu Catholic and Buddhist leaders as representatives of religions recognized by the $\operatorname{state}^{12}$. In this deliberation, the government proposed a body that specifically handles religious issues, which is called the Inter-Religious Consultative Body. This deliberation resulted in the Joint Decree (SKB) of the Minister of Religion and the Minister of Home Affairs No. 1 of 1969 concerning the Implementation of State Apparatus Duties in Ensuring Religious Order and Harmony and the Implementation of Religious Worship. With the issuance of this regulation, the government through the Minister of Religion who was then held by the Minister of Religion Alamsyah Ratu Perwiranegara formed a forum for the Inter-Religious Deliberation Forum (WMAUB). ${ }^{13}$

WMAUB was formed based on three important points in an effort to maintain religious harmony, (1) maintaining internal religious harmony, (2) maintaining harmony between inter-religious communities, (3) harmony between religious communities and the government. In the next period of government of the minister of religion, an Institute for the Study of Religious Harmony (LPKUB) was formed to follow up on the previous organization. However, the optimization of these two institutions (WMAUB \& LPKUB) is considered less than optimal because they do not touch the grassroots community and only stuck at studies of the phenomenon of religious harmony without any local presence. The SKB decree No.1 of 1969 is also considered to be less than optimal in discussing the issue of

\footnotetext{
11 Ibid, p. 33.

12 As for the Confucianism, it was banned in Soeharto era, and does not recognized as a religion in Indonesia. However, after the Soeharto era, in the era of the Abdurrahman Wahid (Gus Dur) presidency, the Confucianism was re-recognized as a religion.

13 Masykuri Abdillah, "Alamsjah Ratu Perwiranegara; Stabilitas Nasional dan Kerukunan” in Azyumardi Azra (ed.), Menteri-Menteri Agama RI Biografi Sosial-Politik (Jakarta: Badan Litbang Departemen Agama RI, 1998), 341.
} 
maintaining religious harmony, one of which is related to the issue of religious order and permits to build houses of worship. So that the government reviews and formulates regulations with the Minister of Religion and the Minister of Home Affairs (PBM) Number 9 and Number 8 of 2006 concerning Guidelines for Implementing Regional Head/Deputy Regional Head Duties in maintaining religious harmony, empowering the Forum for Religious Harmony (FKUB), and permit to establishment of places of worship. ${ }^{14}$ This regulation demonstrates the government's efforts as a facilitator and consultant for religious affairs of religious communities as well as efforts to prevent violations of the rights to freedom of religion or belief.

However, in practice, several regional governments are deemed to have failed to comply with the substance of the regulations contained in the PBM 8/9. This is reflected in the regional regulations that go beyond the substance of the PBM, or even contradictory. Meanwhile, the issuance of permits to build houses of worship is not as easy as imagined and often stumbles upon administrative requirements and other matters. At the same time, interfaith tensions were heating up and often broke out. It is not surprising that the issue of rejecting the construction and repair of places of worship has become the most prominent issue in the discussion on religious freedom and harmony. ${ }^{15}$ Thus, in this case the role of FKUB as guarantor and protector of Forb and community rights is considered weak and failed. In addition, the PBM 2015 evaluation data by The Indonesian Institute regarding the effectiveness of FKUB states that FKUB members' recruitment is not directly proportional to the number of religious believers in an area and has unclear work programs and activities. ${ }^{16}$ This case at least raises various questions related to the implementation of policies in protecting the rights of FORB and the management of religious harmony which is managed by the government through its legalized authority where cases of

\footnotetext{
${ }_{14}$ Kustini (ed.), "Peranan Forum Kerukunan Umat Beragama dalam Pelaksanaan Pasal 8, 9, dan 10 Peraturan Bersama Menteri Agama dan Menteri Dalam Negeri No. 9 dan 8 of 2006," (Jakarta: Research and Development Agency and Education and Training Ministry of Religion, 2010), 190.

15 Marzuki, "Politik Hukum Hak Asasi Manusia Tentang Kebebasan Beragama Pasca Orde Baru", Ius Quia Iustum Law Journal, Indonesia Islamic University, Vol. 26, No. 2, May 2019: 215-237.

16 https://www.theindonesianinstitute.com/category/publikasi/policy-brief/.
} 
religious intolerance and violations of Forb as aspects of civil rights that must be protected by the government often occur.

\section{The Strategic Role of FKUB}

Based on the Joint Ministerial Regulation (PBM) No. 9 and 8 of 2006, the roles and duties of local / regional governments through FKUB institutions generally include the implementation of religious dialogue through religious and community leaders, receiving opinions from mass organizations and community leaders, following up on community aspirations to the local government and provide recommendations for government policies in accordance with the aspirations of the community and religious leaders as well as disseminate these policies to the public. From this decision, it is emphasized that the role of FKUB is not related to understanding the theological doctrines of certain religious teachings, but rather the maintenance of public order. So that it does not raise public suspicion of a government movement that inclined towards a certain religion, such as Christianization ${ }^{17}$ or Islamization. ${ }^{18}$ Furthermore, the role of regional heads also supports the work program activities of FKUB institutions by involving various elements of society. The task of community empowerment is aimed to resolve religious conflicts, cases of religious intolerance and discrimination of religious minorities. This program can be socialized through various programs such as interfaith dialogue, educational seminars and visiting agenda to places of worship. This socialization process also needs to involve interfaith leaders, community leaders and the community in general in order to reach an agreement.

As for encouraging the FKUB work program with the government, each region was asked to form a FKUB advisory board consisting of a regional head/representative, the local Ministry of Religion and Kesbangpol (National Unity and Politics Division). The results of this outreach activity are then written in the form of recommendations addressed to central governments which are subsequently ratified as regional regulations or governor regulation. Based on data compiled by PUSAD Paramadina, there are at least 23

\footnotetext{
${ }^{17}$ For the history of Christianity in Indonesia, Read Jan Sihar Aritonang and Karel A. Steenbrink (eds.), A History of Christianity in Indonesia (Boston: Brill, 2008).

${ }^{18}$ Read Merle Calvin Ricklefs, Islamisation and Its Opponents in Java: A Political, Social, Cultural, and Religious History, C. 1930 to the Present (Hawaii: University of Hawaii Press, 2012).
} 
governor regulations regarding FKUB and FKUB Advisory Board as well as 3 governor regulations regarding places of worship. This regulation has also been updated and followed up by regents and mayors' regulations related to FKUB such as in Bantul and Gunung Kidul districts in D.I. Yogyakarta. ${ }^{19}$

The strategic role of FKUB related to maintaining Forb rights and religious harmony in implementing PBM 2006 in detail can be seen at several points:

First, provincial and district/city FKUBs conduct dialogues with religious and community leaders, both formally and informally. Dialogue can also take the form of religious visits, social institutions run by the religious government. The purpose of this program is to provide values of religious tolerance and work together to maintain religious harmony.

Second, to accommodate the aspirations of religious mass organizations and the aspirations of the community regarding religious life. This task is also assigned to the provincial and district/city FKUB. This aspiration can be obtained through representatives of local religious organizations and religious assemblies. This representative also involved FKUB membership which represented these mass organizations.

Third, channeling the aspirations of religious mass organizations and the community in the form of recommendations as material for regional head policies. At this point, FKUB is a bridge between the community, mass organizations and religious leaders to the local government where all kinds of problems related to religious life will then be formalized according to the recommendations of the regional regulations.

Fourth, to disseminate information on laws and policies in the field of religion related to religious harmony and community empowerment. This task needs to look at the context and map its targets and implementation instruments such as actors, materials, targets and successes.

Fifth, provide written recommendations on applications for the establishment of houses of worship. This task is only assigned to the Regency/City FKUB. This task concerns permits and

19 Pusat Studi Agama dan Demokrasi (PUSAD), "Ringkasan Laporan Riset: Meninjau Kembali Peraturan Bersama Menteri 2006 dan Peran Forum Kerukunan Umat Beragama: Temuan Pangkalan Data," (Jakarta: Paramadina, 2020), 10. 
recommendations for the construction of houses of worship in accordance with the mechanisms set out in the PBM 2006. These recommendations must be based on formal and administrative requirements that have been determined, tracing correct field observations $^{20}$.

In addition, there are several FKUB duties and roles related to the maintenance of religious harmony, namely:

First, to detect and map any potential disturbances to the harmony of religious life. FKUB as a medium for promoting religious harmony is obliged to identify the influences that can trigger religious tension. These influences can be external, such as political, economic, and ethnic. Meanwhile, internal influences can be in the form of blasphemy, doctrine of the spread of religion and religious discrimination.

Second, reducing social tensions that potentially lead a religious conflict and seeking solutions of long and short-term solution through negotiation and mediation processes. Other measures that can prevent social and religious tensions can be implemented through projects to empower youth communities as agents of promoting religious harmony.

Third, making use of local wisdom that can support harmony between religious communities. Local wisdom as one of the characteristics of the Indonesian nation plays an important role in people's lives. Thus, a study that can fill the cultural void of values of religious harmony is needed. The government through FKUB needs to revitalize the local wisdom of the community as a medium to encourage the spirit of harmony. The government also needs to take advantage of communication and information technology to support local wisdom because a lot of local wisdom that has long been maintained is starting to erode along with technological advances in the current era of modernization.

In general, FKUB activities can be in the form of socialization programs and community empowerment programs. Based on data compiled by PUSAD Paramadina in 2020, only 36 percent of FKUB have routine activities to carry out their tasks. ${ }^{21}$ This data shows that FKUB's role is not really active in the project of maintaining the right

20 https://balitbangdiklat.kemenag.go.id/berita/lingkungan-dan-peran-strategisfkub-dalam-pemeliharaan-kerukunan-umat-beragama-dan-persatuan-nasional.

21 Pusat Studi Agama dan Demokrasi, "Ringkasan Laporan Riset," 29. 
to freedom of religion and religious harmony. Moreover, programs carried out are only in the form of internal and external meetings with the aim of broadening the network and insight into the diversity of members. Meanwhile, the FKUB work program related to the maintenance of religious life only focuses on one problem, such as the permitting of places of worship, while rarely are the issues of tolerance, fostering and community empowerment realized for example programs that counter the issues of radicalism circulating on social media, hoaxes, hate-spin to terrorism.

In fact, these issues are very important in the effort of maintaining religious relations and preventing human rights violations. For this reason, it is necessary to create a community empowerment movement that focuses on overcoming these problems. It can be in the form of religious dialogue, information media, social activities, and other positive innovations. This is because of seeing the map of the dissemination of information such as hatespin massage which often takes the name of religion and religious symbols. ${ }^{22}$ This phenomenon does not only have the potential for religious conflict, but also for social degradation.

Several cases of religious conflict caused by the spread of hatespin issues have also been recorded in historical documents of religious life in Indonesia, such as the Poso conflict (1998), ${ }^{23}$ the Ahmadiyah and Shia conflict (2012), ${ }^{24}$ and the religious conflict in Situbondo (1996). These conflicts broke out because one party from a particular religion and group felt aggrieved and insulted by the treatment of other religious groups. Plus, a propaganda message that amplifies the dispute. In the context of such cases, FKUB needs to look back at the background of the conflict used, and what approach is needed in line with the principles of state nationalism. In order to

\footnotetext{
22 Read Cherian George, Hate Spin The Manufacture of Religious Offense and Its Threat to Democracy (Cambridge: MIT Press, 2016).

23 One of the interesting books concerning the Poso Conflict was written by Dave McRae, A Few Poorly Organized Men: Interreligious Violence in Poso, Indonesia (Boston: Brill, 2013).

${ }^{24}$ For more information about Syiah and Ahmadiyah conflict in Indonesia, read Cahyo Pamungkas, Mereka yang Terusir: Studi Tentang Ketahanan Sosial Pengungsi Abmadiyah dan Syiah di Indonesia (Jakarta: Yayasan Obor Indonesia: 2016); Muhammad Afdillah, Dari Masjïd ke Panggung Politik: Melacak. Akar-Akar Kekerasan Agama Antara Komunitas Sunni dan Syiah di Sampang, Jawa Timur (Yogyakarta: CRCS UGM, 2016).
} 
prevent these cases from recurring, the government through the competent institutions such as FKUB needs to carry out a program that contains the values of nationalism, humanity and brotherhood for religious people.

\section{What must be Handled between Religious Harmony and Protecting FORB?}

The discourse on the relationship between religions is generally discussed in two terms, namely Religious Harmony and Religious Freedom. If we interpret a relationship between religions in terms of harmony, then we need to look again at the aspects that must be built to achieve that harmony. Basically, the level of relations between religions is determined by the extent to which the level of social acceptance formed in a community group. If a group accepts another group, without seeing each other as a threat, harmony will automatically create. Even a group will not disturb and feel disturbed by the differences they have. In other words, the factors that can create harmony are social awareness of acceptance of diversity, religious teachings that teach unity in diversity and the role of government with the support a dialogue of diversity. However, from these three aspects, the role of the government is often an obstacle to the protection of the right to Forb and religious harmony.

If we look at a number of incidents or conflict in the establishment of places of worship in Indonesia, they are identified due to administrative constraints issued by the government through regulations. In the case of GKI Yasmin Bogor, in 2010, the rejection of this church was preceded by 30 residents on the grounds that the construction of this house of worship did not get the signature permission of number of residents, did not have a written recommendation letter issued by the local government and FKUB, and did not comply at least 40 household heads in that area. In addition, there are allegations of signature forgery to achieve the minimum number of supporters for the construction of this place of worship.

This rejection is actually not solely based on the number of religious people in the area, but is based on the existence of prejudice and social rejection between religious groups. Also, the lack of clarity about the government's actions in the case of the GKI Yasmin rejection has also contributed to increase religious tensions. Even 
though this tension did not break out into an open conflict, the level of cases of religious intolerance was recorded to have greatly increased. If this intolerant act continues, it will damage the harmony of religious relations, especially between Muslims and Christians. It is proven that even though in 2012, there was positive progress in the GKI Yasmin case, with the issuance of a circular to relocate GKI Yasmin to the Central Bogor area, but cases of violations that occurred in the city of Bogor remained at a high level. This can be proven by the results of a survey by Wahid Foundation (2012) after the problems with the construction of the Yasmin church, where West Java including Bogor is the province with an index of cases of religious intolerance.

In other cases, the problem of violations to freedom of religion or belief also occurs due to a lack of social acceptance among religious groups, which has resulted in cases of intolerance and violations of the right to freedom of religion. The rejection of the GBI houses of worship was caused by the majority of the congregation in a different location from the location where the church was built. Although historically the church location has had a construction permit since 1998, FKUB has been unable to provide recommendations for the establishment of places of worship because there are still no administrative requirements that have not been fulfilled. So that the FKUB recommendation given to the government is to facilitate the location of church construction elsewhere.

The church congregation, which in fact is a minority, feels unfair about the policies issued by the government. The elites who are in charge of conflict resolution, because they want to immediately end the conflict, tend to side with those who are strong. Instead of being a mediator who supposed to act neutral and fair, in accordance with regulations and agreements, they are often trapped in following the wishes of the majority group with pseudo-conflict resolution. As a result, what is called victimizing victim often occurs. Victims who want to seek justice are instead led into a group that has to give in and are forced to follow the will of the majority. The government and the institutional interfaith mediation (FKUB) should strengthen its strategic role as conflict mediator as well as protect the rights to Forb by seeking a dialogue, mediation and negotiation perspective. The government provides an opportunity for parties in conflict to 
dialogue the root of the problem and find solutions together without sacrificing the rights of either party.

\section{Conclusion}

The phenomenon of violations of the right to freedom of religion or belief and religious intolerance, especially regarding cases of freedom of worship, still frequently occurs in Indonesia. As explained that FKUB was formed based on the principles of justice and diversity of society in Indonesia so that the objectivity of its task is to maintain religious harmony and freedom of religion. The government through certain regulations and institutions needs to review approaches of prevention and handling the conflicts where religious violence often occurs because of the alignments of regulations which are considered discriminatory in practice. Bureaucratic justice, such as approving permits to build houses of worship, controlling community interests without violating the rights of minority groups need to be carried out transparently and clearly in accordance with the agreement stipulated in the PBM 2006.

In addition, FKUB is believed to have a strategic role in resolving the phenomenon of religious conflict and violations of Forb rights. However, these phenomena become a homework for the Indonesia as well as a challenge that must be answered not only by the government itself but also by society as a whole. To be emphasized, the government is only a facilitator and protector of the law on religious life while the community is the main driving force or actor. It can be done by two ways, strengthening mediation and negotiation skills on the part of FKUB itself, and embedding insights about diversity, tolerance to society and building their social acceptance.

\section{References:}

\section{Books and Articles}

Afdillah, Muhammad. Dari Masjid ke Panggung Politik: Melacak, AkarAkar Kekerasan Agama Antara Komunitas Sunni dan Syiah di Sampang, Jawa Timur. Yogyakarta: CRCS UGM, 2016.

$\mathrm{Al}$ Qurtuby, Sumanto. Religious Violence and Conciliation in Indonesia:

Christian and Muslims in the Moluccas. London: Routledge, 2016.

Aritonang, Jan Sihar and Steenbrink, Karel A. (eds.). A History of Christianity in Indonesia (Boston: Brill, 2008). 
Azra, Azyumardi (ed.). Menteri-Menteri Agama RI Biografi Sosial-Politik. Jakarta: Badan Litbang Departemen Agama RI, 1998.

Bagir, Zainal Abidin and Asfinawati, et. al. Membatasi Tanpa Melanggar. Yogyakarta: Center for Religious and Cross-cultural Studies, 2019.

Bagir, Zainal Abidin. The Politics of Law of Religious Governance in Muslim and Religious Plurality. London: Routledge, 2018.

Crouch, Melissa. Law and Religion in Indonesia. London: Routledge, 2014.

George, Cherian. Hate Spin The Manufacture of Religious Offense and Its Threat to Democracy. Cambridge: MIT Press, 2016.

Hafiz, Muhammad and Djafar, Alamsyah M. Ringkasan Kebijakan Kemerdekaan Beragama atau Berkeyakinan di Indonesia dan Perlindungan Negara. Jakarta: Wahid Foundation, 2016.

Human Rights Watch. "In the Name of Religion: Violations of Religious Minorities in Indonesia." USA: Human Rights Watch, 2013.

Kustini (ed.). "Peranan Forum Kerukunan Umat Beragama dalam Pelaksanaan Pasal 8, 9, dan 10 Peraturan Bersama Menteri Agama dan Menteri Dalam Negeri No. 9 dan 8 of 2006." Jakarta: Research and Development Agency and Education and Training Ministry of Religion, 2010.

Marzuki. "Politik Hukum Hak Asasi Manusia Tentang Kebebasan Beragama Pasca Orde Baru." Ius Quia Iustum Law Journal, Indonesia Islamic University, Vol. 26, No. 2, May 2019.

McRae, Dave. A Few Poorly Organized Men: Interreligious Violence in Poso, Indonesia. Boston: Brill, 2013.

Mujiburrahman. Feeling Threatened: Muslim-Christian Relation in Indonesia's New Order. Leiden: Amsterdam University Press, 2006.

Pamungkas, Cahyo. Mereka yang Terusir: Studi Tentang Ketahanan Sosial Pengungsi Ahmadiyah dan Syiah di Indonesia. Jakarta: Yayasan Obor Indonesia: 2016.

Pusat Studi Agama dan Demokrasi (PUSAD). Ringkasan Laporan Riset: Meninjau Kembali Peraturan Bersama Menteri 2006 dan Peran Forum Kerukunan Umat Beragama: Temuan Pangkalan Data. Jakarta: Paramadina, 2020. 
Ricklefs, Merle Calvin. Islamisation and Its Opponents in Java: A Political, Social, Cultural, and Religious History, C. 1930 to the Present. Hawaii: University of Hawaii Press, 2012.

\section{Website}

https://balitbangdiklat.kemenag.go.id/berita/lingkungan-dan-peranstrategis-fkub-dalam-pemeliharaan-kerukunan-umat-beragamadan-persatuan-nasional.

https://balitbangdiklat.kemenag.go.id/berita/lingkungan-dan-peranstrategis-fkub-dalam-pemeliharaan-kerukunan-umat-beragamadan-persatuan-nasional.

https://setara-institute.org/laporan-tengah-tahun-kondisi-kebebasanberagamaberkeyakinan-dan-minoritas-keagamaan-di-indonesia2018/.

https://www.theindonesianinstitute.com/category/publikasi/policybrief/. 